Discussion Paper No. 14-032

The Determinants of Private Flood Mitigation Measures in Germany Evidence from a Nationwide Survey

Daniel Osberghaus

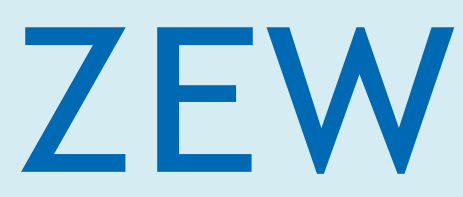

Zentrum für Europäische Wirtschaftsforschung $\mathrm{GmbH}$ Centre for European Economic Research 
Discussion Paper No. 14-032

\section{The Determinants of Private Flood Mitigation Measures in Germany - Evidence from a Nationwide Survey}

Daniel Osberghaus

Download this ZEW Discussion Paper from our ftp server:

http://ftp.zew.de/pub/zew-docs/dp/dp14032.pdf

Die Discussion Papers dienen einer möglichst schnellen Verbreitung von neueren Forschungsarbeiten des ZEW. Die Beiträge liegen in alleiniger Verantwortung der Autoren und stellen nicht notwendigerweise die Meinung des ZEW dar.

Discussion Papers are intended to make results of ZEW research promptly available to other economists in order to encourage discussion and suggestions for revisions. The authors are solely responsible for the contents which do not necessarily represent the opinion of the ZEW. 


\title{
The Determinants of Private Flood Mitigation Measures in Germany - Evidence from a Nationwide Survey
}

\author{
Daniel Osberghaus \\ Centre for European Economic Research; L7, 1; 68161 Mannheim, Germany \\ Tel. +49-621-1235-205 \\ osberghaus@zew.de
}

May 2014

\begin{abstract}
Public flood protection cannot totally eliminate the risk of flooding. Hence, private mitigation measures which proactively protect homes from being flooded or reduce flood damage are an essential part of modern flood risk management. This study analyses private flood mitigation measures among German households. The dataset covers more than 6000 households from all parts of the country, including flood plains as well as areas which are typically not at a high risk of riverine flooding. The results suggest that the propensity to mitigate flood damage increases i.a. with past damage experience and damage expectations for the future. The latter effect can be interpreted as a 'climate adaptation signal' in the flood mitigation behaviour. All other factors remaining equal, a strong belief in a climate-change-induced increase of personal flood damage in the next decades induces an increase of the probability of flood mitigation by more than 10 percentage points. Moreover, strong evidence for moral hazard effects in the flood mitigation behaviour cannot be observed. Households expecting insurance coverage do not reduce their mitigation efforts. Likewise, the expectation of government relief payments hinders mitigation only for some groups of households.
\end{abstract}

\section{Keywords}

Climate change; Adaptation; Flood mitigation; Moral hazard; Charity hazard; Germany

\author{
JEL Codes \\ Q54; D81; R22
}

\section{Introduction}

Flood events can have devastating social, psychological, and economic effects. Two recent major flood events in Germany have demonstrated that also a European high-income country can be severely hit by riverine floods. In 2002, the river floods of Elbe, Danube, and some of their tributaries caused 21 fatalities and economic damages of more than eleven billion euros in Germany (Thieken et 
al. 2005). In 2013, riverine floods of the Elbe, Danube, and others demanded eight fatalities and economic damage of approx. eight billion euros (BMI 2013). While these two major events attracted a lot of media attention, there are further small events like local flash floods or inundations after heavy rain, which may also have severe economic implications for the directly affected households. ${ }^{1}$ Climate change is expected to increase the economic damage due to riverine floods in Europe (Ciscar et al. 2011; Feyen, Barredo, and Dankers 2009; Rojas, Feyen, and Watkiss 2013). For Germany, further analyses demonstrate similar trends (GDV 2011; Hattermann, Huang, et al. 2013). For floods induced by heavy rain, the evidence of a future climate-change-induced increase of economic damage is less clear, but some authors suggest that there is already a significant upward trend in heavy rain events due to climatological drivers such as air temperature (Hattermann, Kundzewicz, et al. 2013; IPCC 2013). This turns public and private preparation for riverine and flash floods into a climate change adaptation measure.

Even without an increase of flood damage, and acknowledging the fact that flood events can never be ruled out by public defence measures, the issue of flood mitigation is a relevant topic. ${ }^{2}$ In Germany, only 33\% of the households are insured against flood damage (GDV 2013). As there is no official public compensation scheme, the majority of the population is left without a guaranteed compensation after a flood event. After large events (in terms of media attention), the federal and state governments have often granted flood relief on an ad-hoc basis (Raschky et al. 2013). For that reason, there is an ongoing debate concerning the necessity of a regime shift in the flood insurance market towards a compulsory flood insurance likewise in other European countries (Choudhry 2013; Mennel and Osberghaus 2013; Schwarze and Wagner 2004). Beside insurance coverage, private flood mitigation measures represent an important part of an integrated flood risk management (Ehrlich and Becker 1972, there called 'self-protection'). Such measures can include the application of waterresistant materials in buildings, removable or fixed water barriers to keep water outside the building, and the flood-adapted use of buildings. According to current German legislation, every potentially affected person has to do whatever is 'possible and reasonable' in order to mitigate flood damage (Wasserhaushaltsgesetz 2009:8, translated by author), and in the national climate adaptation strategy, the federal government states with regard to floods that the 'own precaution behaviour of the population must be strengthened' (Die Bundesregierung 2008:23, translated by author). Empirical analyses from areas which have been flooded in the past have shown that mitigation can indeed effectively reduce economic flood damage considerably and is cost-efficient in many cases (Kreibich, Christenberger, and Schwarze 2011; Kreibich and Thieken 2008).

Given this context, the question arises which households in Germany are presently engaging in private flood mitigation and how can they be characterised? This knowledge can be used to design further policy measures (information campaigns, incentives, or regulations) in order to strengthen the private mitigation behaviour in accordance with the national adaptation strategy.

\footnotetext{
${ }^{1}$ For example, the insured flood damage in Germany in the years between 2003 and 2012, hence in years without major flood events, amounts to. approx. 71 million euros p.a. (own calculations based on GDV 2013) Note that the total flood damage is larger.

2Throughout this article, the term 'flood mitigation' or shortly 'mitigation' will be used to describe measures which are taken before a flood occurs in order to reduce the expected flood damage. Other authors refer to these by the terms 'precautionary measures' or 'proactive flood adaptation'. Private flood mitigation means measures which are taken by private households.
} 
The existing literature on private flood mitigation raises this question and comes to policy-relevant and plausible insights which will be presented in the next section. Our contribution to this literature is the following:

- In contrast to most of the existing studies, we do not focus on a flood-prone or floodexperienced part of the population, but broaden the analysis to the whole country. This is useful for two reasons: First of all, the risk of flood induced by heavy rain is a potential danger to every household in the country. Local examples demonstrate that economic damages from these events should not be neglected (City of Copenhagen 2012; Kandilioti and Makropoulos 2012; Knocke and Kolivras 2007; Veronesi et al. 2013). Secondly, many policies intended to stimulate private flood mitigation are located or debated the national or federal state level. For the design of such policies, insights in the mitigation behaviour of a national household sample are required.

- By restricting the sample to flood-prone regions, a selection bias can occur. It is possible that households located in these areas possess special characteristics which may affect the estimation results. ${ }^{3}$ By extending the analysis to the whole country, we do not expect to have this selection bias.

- By our survey, we approach in particular three possible determinants of private mitigation: The effects of damage experience, of damage expectations, and possible moral hazard effects. None of these relationships have ever been analysed for Germany on a national scale before. As described later, we furthermore deepen the analysis of the effect of damage expectations on private mitigation and identify a non-monotonic climate adaptation signal for private flood mitigation in our sample.

In the remainder of the paper, we review the empirical literature on private flood mitigation in developed countries and present the data, methodology, and the results of the empirical analysis. After checking their robustness regarding various alternative model specifications, we discuss the main results and conclude with a summary and some first policy recommendations.

\section{Literature Review}

There is a growing body of empirical literature on private flood mitigation in developed countries. However, most studies focus on flood-prone or flood-experienced areas and are thereby relatively limited in terms of the studied area and population. Their approaches allow for a very detailed analysis of the impact of flood experiences and effectiveness of mitigation measures, but general conclusions concerning the dissemination and determinants of private flood mitigation in the studied countries are rarely possible. Existing empirical, survey-based studies include many analyses from the Netherlands (Botzen, Aerts, and van den Bergh 2009, 2013; Kievik and Gutteling 2011; Terpstra and Lindell 2012; Zaalberg et al. 2009) and Germany (Bubeck et al. 2013; Grothmann and Reusswig 2006; Grothmann 2005; Koerth et al. 2013; Kreibich et al. 2005, 2009; Thieken et al. 2007). More literature is available on private flood mitigation e.g. in Denmark (Koerth et al. 2013), France (Poussin, Botzen, and Aerts 2013), Italy (Miceli, Sotgiu, and Settanni 2008), Japan (Takao et al. 2004; Zhai et al. 2006), Switzerland (Siegrist and Gutscher 2008), the UK (Bichard and Kazmierczak 2012), and the US

\footnotetext{
${ }^{3}$ We compare our national sample with two subsamples from (a) Saxony and (b) Bavaria by the Wilcoxon ranksum test. Significant differences $(p<.01)$ are present in the distributions of i.a. mitigation behaviour, homeownership, expectation of government relief, and other personal attitudes.
} 
(Carson, McCullough, and Pooser 2013; Lindell and Hwang 2008). The sample sizes of the household surveys and the statistical analyses vary between less than 150 (Koerth et al. 2013) and more than 2000 (Takao et al. 2004). The studied mitigation measures are defined according to the specific contexts and locations but they can be categorised into three groups with regard to their specific scope and purpose (Bubeck et al. 2013; Kreibich et al. 2005): First of all, 'adapted use'-options are behavioural measures which are implemented in order to avoid economic damage in case the house is (partly) flooded, such as avoidance of expensive furnishing in exposed storeys. Secondly, the implementation of 'Flood Barriers' means the installation of water barriers in order to prevent water intrusion into (parts of) the building, such as the installation of backflow flaps and water barriers for cellar openings. Thirdly, 'Structural Measures' are pursued in order to reduce the economic damage in case the house is (partly) flooded and change the structure of the building e.g. using floodresistant paint coats or floor materials. Several studies also count 'information-seeking' as a kind of proactive mitigation measure because informed households possess superior knowledge of how to behave in the case of a flood to keep damages small (Grothmann and Reusswig 2006; Kievik and Gutteling 2011; Koerth et al. 2013; Takao et al. 2004; Terpstra and Lindell 2012; Thieken et al. 2007). Other authors focus on the tangible activities as listed in the categorisation above (Bichard and Kazmierczak 2012; Bubeck et al. 2013; Carson et al. 2013; Zaalberg et al. 2009).

Most of the literature examines inter alia the role of flood damage experience, damage expectations for the future (flood risk perception), and their relationships with flood mitigation. Almost all cited sources find a positive and significant correlation in their sample between flood risk perception and the uptake of mitigation measures. However, the variable measuring flood risk perception is often included in the statistical model as a binary or cardinal variable, not allowing for possible nonmonotonic relationships. The effect of having experienced flood damage is less clear but most studies report a statistically significant positive correlation with private mitigation.

In terms of moral hazard effects, private flood mitigation could be negatively correlated with the expectation of financial damage coverage by (a) an insurance company or (b) some government relief payments - the latter is often referred to as 'charity hazard' and is a special case of moral hazard (Raschky and Weck-Hannemann 2007). The effect of being insured against flood damage on private mitigation is not often analysed. If moral hazard is present in the decision whether to protect against floods or not, insured households should tend to implement less mitigation measures than non-insured, given that both groups are comparable in terms of flood exposure. That means private mitigation is crowded out by insurance. For Florida, Carson et al. find ambiguous relationships of insurance coverage with private mitigation measures (Carson et al. 2013): On the one hand, households with insurance coverage tend to decide for (additional) private mitigation measures, on the other hand the extent of those measures is on average less pronounced than for non-insured households. For the Netherlands, Botzen et al. report a higher self-reported willingness to invest in the elevation of a new house if the respondent is also willing to pay for flood insurance (Botzen et al. 2013). For flood-prone areas in Germany, it seems that insured households take more private flood mitigation measures than non-insured, not less (Thieken et al. 2006). Turning to the effect of expected government relief, some authors indeed report negative correlations with private mitigation (Botzen et al. 2009; Grothmann and Reusswig 2006; Kreibich et al. 2009). However, the charity hazard is not always clearly visible in the data and some estimations fail to discover significant relationships (Bichard and Kazmierczak 2012; Grothmann 2005 for the Rhein area; Koerth et al. 2013). Hence, the empirical evidence for moral hazard in the case of private flood mitigation is 
ambiguous. Indeed, some negative consequences of floods can neither be tackled by insurance nor by state relief, namely the danger to health and life of flooded people, the loss of personal items like photos or memorabilia, and the general inconvenience of being flooded. In case of insurance, there are instruments like deductibles and due diligence clauses which are supposed to limit moral hazard effects. In the light of these considerations and the empirical results, it seems an open question whether moral hazard really is a problem in the case of private flood mitigation.

Concerning further socio-economic variables, the existing empirical literature reports mixed or nonsignificant effects of age. The effects of homeownership, high education, and income are either positive (i.e. higher propensity to mitigate) or non-significant.

Based on this empirical literature, the following questions remain open: Are the relationships of damage experience and damage expectations on the one side and flood mitigation on the other side detectable in a nationwide sample, including households not being located in flood-prone and floodexperienced areas? Is the relationship of expectations and mitigation always monotonic? And are German households subject to moral hazard in the case of private flood mitigation? These questions will be tackled in the following sections.

\section{Data and Methods}

\section{Data set}

Cross section data from a standardised survey among German households is utilised. In total, 6404 households were interviewed via either an online or TV-based questionnaire. The topic was not communicated to the participants beforehand. The survey was conducted in October and November 2012. Towards the end of the survey period, the landfall of hurricane Sandy at the US East coast occurred. This weather event and the resulting substantial damages were an important issue in the German media. $4.4 \%$ of the sample was interviewed after the event. As only heads of households have been interviewed, the sample is largely representative in terms of households but not at the level of individuals. ${ }^{4}$ For the present analysis, the sample is reduced to households who use either a basement or a ground floor. ${ }^{5}$ By that criterion, more than $90 \%$ of the nationwide sample (5851 observations) is potentially exposed to floods from rivers or heavy rain.

Table 1 summarises descriptive statistics of the key variables which are discussed in more detail in the following sections. Descriptive data of various control variables (socio-demographics, personal attitudes, and flood exposure) are presented in Table 7 in the appendix, and the translated questionnaire items for the key variables are given in Table 8 in the appendix. ${ }^{6}$

\footnotetext{
${ }^{4}$ The 6404 participants are a subsample of a representative sample of approx. 10,000 households. Participating households tend to be larger than households in a representative German sample (ratio of single households $25.8 \%$ vs. $40.4 \%$ ). In terms of further comparable household statistics (e.g. income, federal states) our sample is quite representative for Germany. As only heads of households are participating, the statistics of individual characteristics differ from the general population in Germany i.a. in terms of gender (more males in the sample), age (sample is older than population), education (higher education in the sample), and risk attitudes (the sample is slightly less risk averse).

${ }^{5}$ Wilcoxon rank-sum tests suggest that the excluded subsample differs significantly $(p<.1)$ from the remaining households in terms of several socio-economic variables, but not in general risk attitudes.

${ }^{6}$ Beside the topics raised by this article, the participants were asked about their climate adaptation actions in the fields of home cooling and tourism and their general opinions and experiences with regard to climate
} 
Table 1: Descriptive statistics of key variables (full sample of potentially exposed households)

\begin{tabular}{|c|c|c|c|c|c|c|c|}
\hline $\begin{array}{l}\text { Variable in the } \\
\text { model }\end{array}$ & Variable in the data & Mean & Median & $\begin{array}{l}\text { Std. } \\
\text { dev. }\end{array}$ & Min. & Max. & Obs. \\
\hline \multirow{9}{*}{$\begin{array}{l}\text { Private flood } \\
\text { mitigation }\end{array}$} & \multicolumn{7}{|l|}{ Stated implementation of ... } \\
\hline & $\begin{array}{l}\text {... moving valuable assets to higher } \\
\text { floors (not applicable to households } \\
\text { located in one floor) (M1) }\end{array}$ & .0520 & 0 & .222 & 0 (no) & 1 (yes) & 3076 \\
\hline & $\begin{array}{l}\text {... water barriers at basement } \\
\text { openings (not applicable to } \\
\text { households without basement) (M2) }\end{array}$ & .0329 & 0 & .178 & 0 (no) & 1 (yes) & 5139 \\
\hline & $\begin{array}{l}\text {... back flow flap (applicable to } \\
\text { homeowners) (M3) }\end{array}$ & .295 & 0 & .456 & 0 (no) & 1 (yes) & 3374 \\
\hline & $\begin{array}{l}\text {... water-resistant exterior paint coat } \\
\text { (applicable to homeowners) (M4) }\end{array}$ & .145 & 0 & .352 & 0 (no) & 1 (yes) & 3373 \\
\hline & $\begin{array}{l}\text {... water-resistant interior paint coat } \\
\text { (M5) }\end{array}$ & .0314 & 0 & .174 & 0 (no) & 1 (yes) & 5827 \\
\hline & $\begin{array}{l}\text {... water-resistant floor (applicable } \\
\text { to homeowners) (M6) }\end{array}$ & .141 & 0 & .348 & 0 (no) & 1 (yes) & 3372 \\
\hline & $\ldots$ any of the mentioned measures & .272 & 0 & .445 & 0 (no) & 1 (yes) & 5828 \\
\hline & $\begin{array}{l}\text { Planned implementation of any of } \\
\text { the mentioned measures }\end{array}$ & .0647 & 0 & .246 & 0 (no) & 1 (yes) & 4407 \\
\hline $\begin{array}{l}\text { Damage } \\
\text { experience } \\
\text { (past) }\end{array}$ & $\begin{array}{l}\text { Household has already experienced } \\
\text { financial or health damage by floods }\end{array}$ & .116 & 0 & .320 & 0 (no) & 1 (yes) & 5826 \\
\hline $\begin{array}{l}\text { Damage } \\
\text { expectation } \\
\text { (future) }\end{array}$ & $\begin{array}{l}\text { Expected likelihood of an increase in } \\
\text { flood damage on the household } \\
\text { level (very unlikely (1) to very likely } \\
\text { (5)) }\end{array}$ & 2.099 & 2 & 1.047 & 1 & 5 & 5238 \\
\hline \multirow{2}{*}{ Moral hazard } & $\begin{array}{l}\text { Stated flood coverage of home or } \\
\text { content insurance }\end{array}$ & .543 & 1 & .498 & 0 (no) & 1 (yes) & 5709 \\
\hline & $\begin{array}{l}\text { Stated expectation of financial } \\
\text { government relief }\end{array}$ & .316 & 0 & .465 & 0 (no) & 1 (yes) & 5713 \\
\hline
\end{tabular}

As a cross-section, the data set cannot directly depict the time dimension. However, the key variables are quasi-temporal by explicitly asking for the currently implemented measures, measures planned for the future, damage events at any time in the past and expectations for the next decades.

\section{Data: Private flood mitigation}

The uptake of private mitigation is measured by a series of binary questions about the implementation of certain measures as described in more detail in Table $1 .^{7}$ The portfolio of mitigation measures is inspired by the literature on flood mitigation measures in Germany and covers

change. An aggregated overview of key data and more information on the survey, including the questionnaire in German is available in (Osberghaus, Schwirplies, and Ziegler 2013).

${ }^{7}$ Mitigation measures which had been already installed before the participant moved in / purchased the home are not counted by that measure. Hence, the dissemination of flood mitigation measures is slightly underestimated. 
the three different categories as presented in the previous section (M1 is adapted use, $M 2$ and $M 3$ are flood barriers, and M4 to M6 are structural measures). We concentrate on the analysis of tangible activities rather than the information level of households. This means that our evaluation of general flood mitigation behaviour in Germany could be rather conservative, missing those households who are well-prepared in terms of knowledge about emergency measures but not in terms of tangible proactive measures. Explicit 'don't know' -answers were coded as if the household has not implemented the measure because it can be assumed that such participants have not deliberately and intentionally taken the measure. Missing answers, however, were treated as missing values. As our main interest lies in the general decision to take private mitigation (in any form) and we do not focus on the determinants of the specific measures, we construct an aggregate variable which takes the value of one if one or more of the available mitigation measures has been implemented by the respective household and zero otherwise. This is also rationalised by the fact that the data does not indicate which of the alternative measures is the most appropriate for a specific household. In an area with typically high groundwater levels, water barriers may be useful whereas in other areas backflow flaps could be more efficient because the local sewage system is relatively often overloaded. By using the aggregate variable, we just analyse the general decision whether to implement some mitigation measures or not, regardless of the household's (very contextspecific) decision which measure or combination of measures is preferred.

The mitigation variable differs considerably between homeowners and tenants: The share of mitigating homeowners is $44.1 \%$, the share of mitigating tenants only $3.9 \%$. This discrepancy is not only due to the arguably higher motivation to protect the own home but also implied by the construction of the mitigation variable. The aggregate variable includes three mitigation measures which are only applicable to homeowners; consequently homeowners have a higher probability to mitigate by construction of the data. As we are interested in other determinants and the effect of homeownership can be controlled for, we will proceed with the aggregate mitigation variable (share of homeowners in the sample: 58.3\%; in Germany in 2013: 43.0\%).

For an analysis of causality, we elicit the participants' stated intentions for future implementation of mitigation measures (unless already implemented). The rationale is that possible determinants should stimulate plans to implement mitigation measures in the near future, but not vice versa. For reasons of sample size and because of the small number of planning households, we use the implementation variable for the main analyses and the planning variable as a robustness check.

\section{Data: Flood exposure}

Regarding the control variables which capture the households' exposure to flood risk, we have to rely on a quite crude approximation. A general exposure index to floods including flash floods would have to consider site-specific topography, hydrological data (e.g. river runoff, local precipitation, percolation and evaporation), infrastructures (e.g. dikes, levees, sewage systems, sealed areas) and is still in development stage (GDV 2014). Household-level data on riverine flood risk is known by the insurance industry but is not publicly available. Hence, we use the following set of variables as a rough proxy for flood exposure (descriptive statistics see Table 7 in the appendix). Most of these variables correlate with the statement of having personally witnessed a flood event.

- A dummy variable indicating whether there is a large or medium-size river in the ZIP-code area of the household's residence. 
- Total population of the municipality of the households. This is rationalised by the fact that larger communities are presumably better protected against floods.

- Historical (1981-2010) precipitation for the month with the highest precipitation in the ZIPcode area. This data follows - at least in relative terms - the expected maximum precipitation loads for sewage and drainage systems of the community and hence is used as a proxy for the capacity of these systems. As highly capable sewage systems decrease the risk of flash floods, we expect a negative relation with private mitigation.

- A dummy variable indicating households where only the basement is exposed to floods.

- Federal state dummy variables.

\section{Data: Damage experience}

For measuring past flood damage experience, the participants stated whether they have suffered any financial or health damage due to floods. Thus, the data is a binary measure of the stated flood damage occurrence, albeit without indicating the severity or time of the damage. ${ }^{8}$

\section{Data: Damage expectations}

Expectations regarding the future flood damage are measured by the participant's assessment of the likelihood of a climate-change-induced increase of personal damage in the next decades, ranging on a five-point Likert-scale from 'very unlikely' to 'very likely'. Thus, the data is ordinal with five values. Note that the data does not reveal whether participants expect a damage increase due to other reasons than climate change. Those participants who do not expect a climate change in Germany (5.1\% of the sample) and those who do not expect a climate-change-induced increase in the occurrence of floods or inundations in Germany (additional 6.0\%) were not asked about their expectations of climate-change-induced damage increases. These participants were classified into the lowest expectation category (damage increase is deemed as 'very unlikely'). Whether this data manipulation has an effect on the main results was evaluated in a robustness check regression.

\section{Data: Moral hazard}

Flood insurance coverage was elicited by a series of questions on the holding of policies and coverage(s) of home and/or content insurance contracts. In Germany, almost every homeowner holds a basic home insurance. However, most basic policies cover wind, hailstorm, and fire while other natural hazards, including floods and inundation, have to be covered for an extra premium. The market penetration for home insurances with flood coverage in 2012 was around 33\%, and for content insurance 19\% (GDV 2013). In our sample the respective ratios of participants stating they have flood coverage in their insurance contracts are surprisingly high (59.9\% and $41.3 \%$ for home and content insurance, respectively, after counting the numerous 'don't know' answers as 'no coverage'). These differences imply that either the sample is heavily biased in this respect or many German households overestimate their own insurance coverage and will be negatively surprised in case they like to file a claim after a flood. However, the fact that the data eventually does not measure the real insurance coverage in our sample does not hinder the analysis of moral hazard effects. Indeed the perceived, not the real insurance coverage, may play a role for the decision whether to invest in

\footnotetext{
${ }^{8}$ Many of the available surveys elicit more details and do this for good reasons. They are, however, mostly approaching households located in flood-prone areas or which have recently experienced a flood event. As we are approaching the general public, we assume that - relative to the samples analysed by other studies - many participants do not have a pronounced knowledge, interest or personal experience in the topic of flooding. Hence, we keep these questions short and simple.
} 
(additional) mitigation measures. If perceived insurance coverage goes along with less private flood mitigation as implied by the moral hazard argument, this relationship will be visible in our data.

For the analysis of possible charity hazard effects, we asked whether the participants expect any financial support by some public entity (e.g. federal or state government or municipality) in case that their home or content is damaged by some natural hazard. About a third of the households indeed make such a claim although there is no ex-ante regulation by the German authorities for natural hazard relief payments.

\section{Statistical Methods}

For the analysis of the possible effects of damage experience, damage expectations, and moral hazard effects on private mitigation multivariate regressions are used. As the dependent variable is binary (either the household mitigates or it does not) we employ a probit model. As the data stem from a cross section of a household survey, heteroscedasticity is very likely (Deaton 1997). For that reason, we relax the assumption of homoscedasticity and use heteroscedasticity-robust standard errors introduced by Huber/White (Huber 1967; White 1980, 1982).

The first regressions only include the control variables (presented in Table 7 in the appendix). The variables of interest (damage experience, damage expectations, moral hazard variables) are added in the next regressions - first independently, then all together. As a consequence, we are enabled to assess the marginal effect of the key variables separately and in the context of a full model. Damage expectations are entered by dummy variables (and a reference group), indicating whether the participant chose the respective level of personal damage expectations. This flexible procedure allows for the explicit analysis of the effects of each of the five expectation levels and thereby is able to identify possible non-monotonic effects of damage expectations. Hence, all key variables (one for damage experience, four for damage expectation variables, and two for moral hazard) are dummy variables. Moreover, this set of seven variables is split up into two sets of seven variables each, one for homeowners and one for tenants. For tenants, all seven homeowner-key variables take the value of zero and vice versa. The regression coefficients of these variables can be directly interpreted as the effects of the key variables for homeowners and for tenants, respectively.

The coefficients of the probit model are transferred to marginal effects in order to depict the alteration of estimated probability of mitigation. In reference to the calculation of marginal effects, the marginal effect could be derived for a 'representative' household with covariates at some representative values or the average marginal effects can be calculated with the observed covariates. For some variables in our data, the definition of a representative value is not obvious, so we use average marginal effects. However, for the calculation of marginal effects of homeowner- and tenant-specific effects of the key variables, we set the homeownership-covariate to one for homeowners and zero for tenants and calculate the average marginal effects conditionally on this constraint.

For all regressions, exactly the same sample is used, i.e. households with missing observations in one of the regressions are excluded in every regression. Thereby the sample is reduced to 4272 observations with non-missing data. ${ }^{9}$

\footnotetext{
${ }^{9}$ Wilcoxon rank-sum tests of differences between the excluded and the remaining samples suggest that significant $(p<.1)$ differences in the distributions of the variables gender, age, income, importance of own
} 
In order to check the robustness of the results regarding reverse causality and other possible problems, we conduct several regressions with alternative specifications.

\section{Results and Discussion}

\section{Main results}

Table 2 summarises the results of various probit regressions with the dependent binary variable 'uptake of any private flood mitigation measure'. Five model specifications are presented: Model 1 contains only control variables such as socio-demographics, personal attitudes, and flood exposure; Model $2 \mathrm{a}$ additionally includes damage experience; Model $2 \mathrm{~b}$ focuses on damage expectations and Model $2 \mathrm{c}$ on moral hazard effects. Model 3 is a full model with all variables. Complete results, including the coefficients of all control variables are reported in Table 9 in the appendix (only for Model 3). All results which are not reported in detail are available upon request.

Table 2: Results of probit regressions (average marginal effects). Dependent variable: Uptake of any private flood mitigation measure. ${ }^{*} / * / * * *$ symbolize statistical significance on the $10 / 5 / 1 \%$ level. Robust standard errors for Model 3 are reported in Table 9 in the appendix.

\begin{tabular}{|c|c|c|c|c|c|c|c|}
\hline \multicolumn{3}{|c|}{ Variables } & $\begin{array}{l}\text { Control } \\
\text { variables only } \\
\text { (Model 1) }\end{array}$ & $\begin{array}{l}\text { Damage } \\
\text { experience } \\
\text { (Model 2a) }\end{array}$ & $\begin{array}{l}\text { Damage } \\
\text { expectations } \\
\text { (Model 2b) }\end{array}$ & $\begin{array}{l}\text { Moral hazard } \\
\text { (Model 2c) }\end{array}$ & $\begin{array}{l}\text { All variables } \\
\text { (Model 3) }\end{array}$ \\
\hline \multicolumn{3}{|c|}{ Homeownership } & $.378 * * *$ & $.366 * * *$ & $.377^{* * *}$ & $.348 * * *$ & $.338 * * *$ \\
\hline \multicolumn{3}{|c|}{ Further control variables } & included & included & included & included & included \\
\hline \multicolumn{3}{|c|}{ Damage experience of homeowners } & - & $.238 * * *$ & - & - & $.210 * * *$ \\
\hline \multicolumn{3}{|c|}{ Damage experience of tenants } & - & $.053^{* *}$ & - & - & $.035^{*}$ \\
\hline \multirow{3}{*}{ 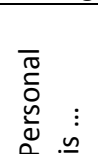 } & ... very unlikely & \multirow{5}{*}{ 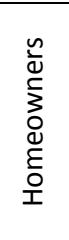 } & - & - & ref. group & - & ref. group \\
\hline & ... rather unlikely & & - & - & .026 & - & .020 \\
\hline & $\begin{array}{l}\text {... moderately } \\
\text { likely }\end{array}$ & & - & - & $.097^{* * *}$ & - & $.074 * * *$ \\
\hline \multirow{7}{*}{ 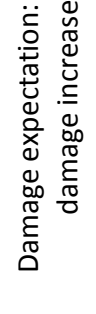 } & ... rather likely & & - & - & $.168 * * *$ & - & $.122 * * *$ \\
\hline & ... very likely & & - & - & $.149 * *$ & - & .068 \\
\hline & ... very unlikely & \multirow{5}{*}{ 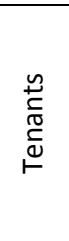 } & - & - & ref. group & - & ref. group \\
\hline & ... rather unlikely & & - & - & .009 & - & .007 \\
\hline & $\begin{array}{l}\text {... moderately } \\
\text { likely }\end{array}$ & & - & - & .024 & - & .017 \\
\hline & ... rather likely & & - & - & $.059 * *$ & - & $.040^{*}$ \\
\hline & ... very likely & & - & - & .047 & - & .024 \\
\hline \multicolumn{3}{|c|}{$\begin{array}{l}\text { Perceived insurance coverage of } \\
\text { homeowners }\end{array}$} & - & - & - & $.108 * * *$ & $.097 * * *$ \\
\hline \multicolumn{3}{|c|}{$\begin{array}{l}\text { Perceived insurance coverage of } \\
\text { tenants }\end{array}$} & - & - & - & $.048^{* *}$ & $.022^{* *}$ \\
\hline \multicolumn{3}{|c|}{$\begin{array}{l}\text { Expectation of government relief of } \\
\text { homeowners }\end{array}$} & - & - & - & $.030 * *$ & $.039 *$ \\
\hline \multicolumn{3}{|c|}{$\begin{array}{l}\text { Expectation of government relief of } \\
\text { tenants }\end{array}$} & - & - & - & .006 & .003 \\
\hline \multicolumn{3}{|c|}{ Pseudo-R2 } & .228 & .242 & .235 & .235 & .253 \\
\hline \multicolumn{3}{|l|}{$\mathrm{N}$} & 4272 & 4272 & 4272 & 4272 & 4272 \\
\hline
\end{tabular}

The results can be summarised as in the following: The overall fit of the model is quite good for the full sample (McFadden's-Pseudo-R2 of 0.253, Nagelkerke-R2 of 0.374 in Model 3). Damage experience (i.e. whether a household has already suffered any financial or health damage due to a

financial situation, insurance coverage, damage experience, and knowledge of flood risk are prevailing. Hence, we check the robustness of our main results in regressions with less missing observations, including each key explanatory variable separately. 
flood any time in the past) is a stable and highly significant explaining variable for private mitigation. Damage expectations for the future present a positive relationship with the decision for mitigation measures (especially for homeowners) but for very pessimistic expectations the relationship becomes less pronounced and less significant. Households (particularly homeowners) who expect their damage to be (partly) covered by a third party tend to implement mitigation measures relative to those without this expectation.

Turning to individual household control variables, there are significant and intuitive results regarding household income, materialism attitudes, and knowledge of flood risk (see Table 9 in the appendix). There is a counterintuitive positive relationship between risk seeking and mitigation, to which we will come back to in the discussion of moral hazard effects. In terms of exposure variables, there are expected significant correlations between private flood mitigation and population of the community and historical precipitation amounts in the wettest month (as a proxy for the capacity of sewage and drainage systems), while the other exposure variables remain insignificant.

Before investigating these results more deeply in the discussion section, we check their robustness regarding alternative model specifications.

\section{Robustness checks}

A further regression has been estimated with the stated intention to engage in some form of mitigation in the future as the dependent variable - in contrast to the already fulfilled implementation. Due to the very small number of tenants planning to engage in mitigation $10.7 \%$ of the estimation sample), a differentiated estimation of the key variable effects is problematic, and we combine homeowners' and tenants' effects. Regarding damage experiences and expectations of households, the results are qualitatively the same, showing that current expectations serve as a motivation to implement mitigation measures. If the causality had been reversed, the relationship would not hold in the regression on planning. The coefficient of perceived insurance coverage, however, becomes small and insignificant.

As described in the data section, the expectation variable of some participants has been set to the lowest category ('very unlikely') because they either do not expect climate change to happen in Germany or do not expect a climate-change-induced increase in the occurrence of floods in Germany. Regressions without these participants showed no qualitatively different results in the key variables.

It has been mentioned that the sample of households with non-missing values in all explanatory variables differs in some relevant variables from the full sample (see footnote 9 ). To test whether this discrepancy may affect the main results, the Models $2 a, 2 b$, and $2 c$ have been estimated with all available observations (4685, 4322, and 4654 households in Model 2a, 2b, and 2c, respectively). Although this procedure reduces the discrepancies between the estimation samples and the full sample, significant $(p<.1)$ differences remain in gender, age, income, and importance of own financial situation. The main results do not differ from the ones presented in Table 2.

In terms of marginal effects, instead of average effects, the effects for a representative household can be used. We use medians for binary and ordinal values and means for cardinal variables as representative values. The key variable 'marginal effects' for a representative household does not differ substantially from the ones presented in Table 2. 
As an alternative to the binary decision whether to mitigate or not, one could use the number of implemented mitigation measures as dependent variable. This procedure has the caveats that (a) some measures are only applicable for a subset of the sample, (b) measures could be regarded as substitutes and hence an accumulation of measures makes no sense. However, regression results from poisson regressions (which control for the count data characteristic of the dependent variable) show no differences in terms of significance and direction of the analysed effects.

\section{Effect of damage experience}

The abovementioned results regarding flood damage experience are quite plausible and expected in terms of signs and significance levels. Most of the existing literature comes to similar conclusions. Interestingly, this effect seems also be statistically significant and robust in a nationwide survey which is not dominated by participants from flood-prone or flood-experienced areas. Using the results from Model 3 in Table 2, predictions of the (change of) mitigation behaviour, depending on damage experience, are possible (see Table 3).

Table 3: Predicted probabilities of flood mitigation depending on flood damage experience and average marginal effects of experience, based on results of Model 3. $* / * * * * *$ denote statistical significance on the $10 / 5 / 1 \%$ level for the marginal effects.

\begin{tabular}{|l|l|l|l|l|}
\hline & \multicolumn{2}{|c|}{ Homeowners } & \multicolumn{2}{c|}{ Tenants } \\
\cline { 2 - 5 } & $\begin{array}{l}\text { Predicted } \\
\text { probability }\end{array}$ & Marginal effect & $\begin{array}{l}\text { Predicted } \\
\text { probability }\end{array}$ & Marginal effect \\
\hline No flood experience & .355 & $.210 * * *$ & .039 & $.035^{*}$ \\
\hline Flood experience & .564 & .074 & & .046 \\
\hline $\begin{array}{l}\text { Observed ratios of } \\
\text { mitigating households }\end{array}$ & \multicolumn{2}{|c|}{.457} & &. \\
\hline
\end{tabular}

The predicted probabilities mirror the abovementioned differences between homeowners and tenants, which are partly due to the construction of the dependent variable and should therefore not be interpreted as the effect of owning a house. The results show the high relevance and significance of damage experience from a flood event for the homeowners' decision to engage in mitigation measures. For tenants, the marginal effect of flood experience is less significant.

\section{Effect of damage expectations}

By explicitly asking for the expectation of a climate-change-induced increase of personal damage, the expectation variable can be used as a rough proxy for private climate change adaptation in flood mitigation behaviour. Using the same prediction procedure as for the effect of damage experience, the effect of damage expectations on predicted mitigation behaviour can be depicted as in Figure 1 . 


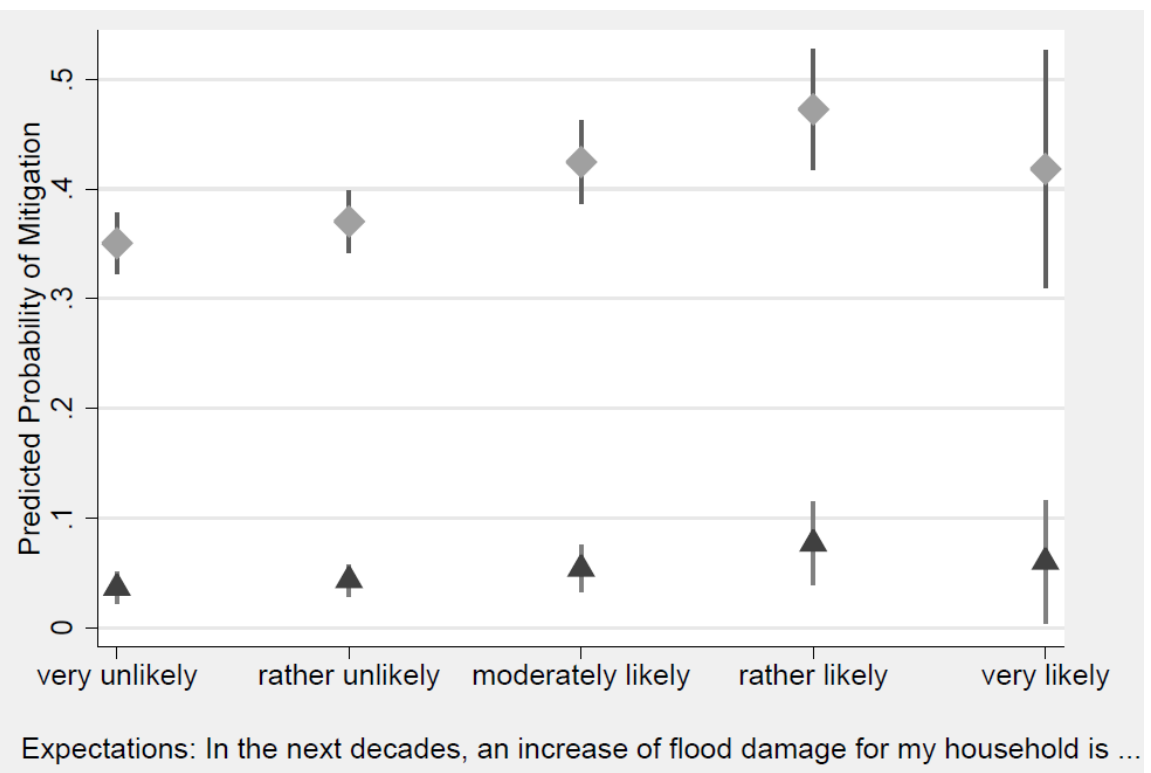

Figure 1: Predicted probabilities and $90 \%$-confidence intervals of flood mitigation depending on flood damage expectations, based on results of Model 3. The diamonds depict values for homeowners and the triangles for tenants, respectively. The respective observed ratios of mitigating households are reported in Table 3.

Several insights become apparent in Figure 1: For tenants, expectations of climate-change-induced damage increases seem to be of low relevance for the decision to mitigate. Only those tenants who deem a damage increase as 'rather likely' exhibit a significantly higher probability to mitigate than those with the lowest expectation level $(p<.1)$. This is just the graphical illustration of the low statistical significance of the expectations effects for tenants in Table 2. Hence, we can only identify a weak climate adaptation signal in the flood mitigation behaviour of tenants. One reason could be the lower motivation to invest in measures. Some measures can incur non-negligible costs when being insecure how long the benefits will be available. Furthermore, tenants could have less emotional commitment to the building and hence less intrinsic motives for protecting it from floods.

For homeowners, there is generally a positive and significant correlation between damage expectations and the decision to mitigate, in particular if a climate-change-induced damage increase is deemed as 'moderately likely' or higher $(p<.01)$. This can be interpreted as the climate adaptation part in the flood mitigation of private homeowners. The adaptation signal can induce an increase of more than $10 \%$ in the predicted probability of mitigation.

An increase in private flood mitigation when households perceive a higher flood risk in the future is plausible and well documented in other studies. Indeed, the predicted probabilities to mitigate increase monotonically for homeowners who perceive a personal damage increase as between 'rather unlikely' and 'rather likely'. However, between the extreme expectation levels ('very unlikely', $\mathrm{N}=877$ and 'very likely', $\mathrm{N}=49$ ) and the respective adjacent categories, the differences in the estimated mitigation probabilities are not significant. Thus, we cannot confirm a monotonic increase in flood mitigation over all levels of damage expectations. Our results rather suggest that there are 'threshold values' in the climate change expectations regarding their effect on flood adaptation. Below some lower threshold, no adaptation behaviour can be expected, and above some upper threshold, existent adaptation efforts are probably not further intensified. This would mean that for a group of households with expectations right below the lower threshold a small increase in damage expectations would imply initial engagement in adaption, whereas households with expectations far 
below this threshold would not change their behaviour if their expectation level would increase by the same magnitude. Likewise, there can be households who are not further increasing their flood mitigation engagement after being more convinced of climate-change-induced damage. However, this result has to be seen with caution. Remember that in our data climate change expectations are measured by the expected probability that some event (the increase of personal flood damage due to climate change) will happen in the next decades. Various other formulations of climate change expectations are feasible. To what extent the concrete formulation plays a role for the existence of the abovementioned thresholds might be a topic for further research.

\section{Moral hazard effects}

It should be noted again that the insurance variable in our data is not a reliable measure for the actual flood insurance coverage, but is driven by the participants' evaluation of their own coverage. The differences may be large, as discussed before. For identifying possible moral hazard effects, however, the perceived coverage is the appropriate measure. If there is moral hazard in the decision to take private mitigation measures regarding third party insurance, the expectation of coverage should suffice to imply less intense mitigation.

Our data, however, do not suggest a moral hazard phenomenon. In the contrary, the regression coefficients of insurance coverage in almost all specifications are positive and significant, meaning households who expect partly damage coverage by third parties also have a higher probability to take (additional) flood mitigation measures (see Table 4).

Table 4: Predicted probabilities of flood mitigation depending on expectations of damage coverage and average marginal effects of damage coverage expectations, based on results of Model 3. $/ * * / * * *$ denote statistical significance on the 10/5/1 \% level for the marginal effects. The respective observed ratios of mitigating households are reported in Table 3.

\begin{tabular}{|c|c|c|c|c|}
\hline & \multicolumn{2}{|c|}{ Homeowners } & \multicolumn{2}{|c|}{ Tenants } \\
\hline & $\begin{array}{l}\text { Predicted } \\
\text { probability }\end{array}$ & $\begin{array}{l}\text { Marginal } \\
\text { effect }\end{array}$ & $\begin{array}{l}\text { Predicted } \\
\text { probability }\end{array}$ & $\begin{array}{l}\text { Marginal } \\
\text { effect }\end{array}$ \\
\hline No flood insurance coverage expected & .330 & \multirow{2}{*}{$.097 * * *$} & .037 & \multirow{2}{*}{$.022 * *$} \\
\hline Flood insurance coverage expected & .427 & & .059 & \\
\hline No government relief payments expected & .364 & \multirow{2}{*}{$.039 *$} & .040 & \multirow{2}{*}{.003} \\
\hline Government relief payments expected & .402 & & .043 & \\
\hline
\end{tabular}

First, let us discuss the relationship with insurance coverage. This result is difficult to interpret as a causal effect, and indeed the coefficient gets insignificant if future planned mitigation is used as the dependent variable (see section on robustness checks). Instead, it could be interpreted as a correlation: Households with a high awareness of flood risk and a high willingness to engage in counter measures are doing both - insure and take mitigation measures. That would mean that unmeasured household characteristics such as unobserved risk aversion and unobserved exposure levels may cause a spurious correlation between insurance and mitigation. Another possibility to explain the relationship is the awareness and information campaigns of German insurance companies targeting their costumers, propagating the importance and usefulness of private flood mitigation - although the apparent overestimation of the own insurance coverage indicates a rather low information level with regard to private flood response options. In the light of these results it seems that physical flood mitigation measures and financial flood insurance policies are not seen as perfect substitutes, and indeed they partly cover different risks, as discussed before. Similar results (comparably high mitigation behaviour among insured households) are found in other studies for the 
German context (Thieken et al. 2006) and in the USA for wind storm mitigation/insurance (Carson et al. 2013; Chatterjee and Mozumder 2014; Petrolia et al. 2013).

The second counterintuitive effect is the higher propensity of mitigation for homeowners who expect government relief. The way how expectations about ad-hoc government relief are formed and how these expectations influence the decision to mitigate are complex processes which may depend on observed and unobserved personality traits. Hence, we test for various interaction effects of individual control variables with the relationship of relief expectation and mitigation. Indeed, there are significant interaction effects with general risk seeking and education levels, as presented in Table 5 in detail. ${ }^{10}$

Table 5: Results of probit regressions (average marginal effects) with and without interaction between expectation of government relief and (a) risk seeking and (b) education level. Dependent variable: Uptake of any private flood mitigation measure. $* / * * / * * *$ symbolise statistical significance on the $10 / 5 / 1 \%$ level.

\begin{tabular}{|c|c|c|c|c|c|}
\hline \multirow{2}{*}{\multicolumn{2}{|c|}{ Variables }} & \multicolumn{2}{|c|}{$\begin{array}{c}\text { Without interaction variables } \\
\text { (Model 3) }\end{array}$} & \multicolumn{2}{|c|}{$\begin{array}{c}\text { With charity hazard interaction } \\
\text { variables (Model 4) }\end{array}$} \\
\hline & & Homeown. & Tenants & Homeown. & Tenants \\
\hline \multicolumn{2}{|c|}{ Homeownership } & \multicolumn{2}{|c|}{$.338^{* * *}$} & \multicolumn{2}{|c|}{$.331^{* * *}$} \\
\hline \multicolumn{2}{|c|}{ Stated general willingness to take risks } & \multicolumn{2}{|c|}{$.006 *$} & \multicolumn{2}{|c|}{.001} \\
\hline \multicolumn{2}{|c|}{ High education } & \multicolumn{2}{|c|}{.009} & \multicolumn{2}{|c|}{$.031^{* *}$} \\
\hline \multicolumn{2}{|c|}{ Further control variables } & \multicolumn{2}{|c|}{ included } & \multicolumn{2}{|c|}{ included } \\
\hline \multicolumn{2}{|c|}{ Damage experience } & $.210 * * *$ & $.035^{*}$ & $.211^{* * *}$ & $.035^{*}$ \\
\hline \multirow{5}{*}{ 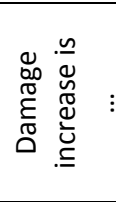 } & ... very unlikely & \multicolumn{2}{|c|}{ reference group } & \multicolumn{2}{|c|}{ reference group } \\
\hline & ... rather unlikely & .020 & .007 & .022 & .006 \\
\hline & ... moderately likely & $.074 * * *$ & .017 & $.077 * * *$ & .017 \\
\hline & ... rather likely & $.122^{* * *}$ & $.040^{*}$ & $.123^{* * *}$ & $.039 *$ \\
\hline & ... very likely & .068 & .024 & .075 & .022 \\
\hline \multicolumn{2}{|c|}{ Perceived insurance coverage } & $.097 * * *$ & $.022^{* *}$ & $.097^{* * *}$ & $.020 *$ \\
\hline \multicolumn{2}{|c|}{ Expectation of government relief } & $.039 *$ & .003 & -.014 & -.011 \\
\hline \multicolumn{2}{|c|}{$\begin{array}{l}\text { Interaction Risk seeking * Expectation of } \\
\text { government relief }\end{array}$} & - & - & $.018^{*}$ & $.006^{*}$ \\
\hline \multicolumn{2}{|c|}{$\begin{array}{l}\text { Interaction: High education * Expectation of } \\
\text { government relief }\end{array}$} & - & - & $-.085^{* *}$ & $-.045 * *$ \\
\hline \multicolumn{2}{|c|}{ Pseudo-R2 } & \multicolumn{2}{|c|}{.253} & \multicolumn{2}{|c|}{.256} \\
\hline \multicolumn{2}{|l|}{$\mathrm{N}$} & \multicolumn{2}{|c|}{4272} & \multicolumn{2}{|c|}{4272} \\
\hline
\end{tabular}

Table 5 shows that the expectation of government relief has ambiguous relationships with the decision to proactively mitigate flood damage. Lower educated and risk seeking participants tend to have a higher probability to mitigate if they expect government aid, while the relation can also be negative for risk-averse and higher educated participants - these participants are subject to charity hazard. By adding up the general effect of government relief expectation and the interaction effects an aggregate effect of government relief expectation conditional on the values of interaction variables (risk attitude and education) can be derived. Combining these aggregate effects with the ratios of observations fulfilling the respective values of interaction variables provides a picture of how many participants are expectedly exhibiting which response to government relief expectation. Table 6 provides an overview of the proportions of homeowners and tenants regarding their individual total effects of government relief expectation, dependent on risk attitudes and education level.

\footnotetext{
${ }^{10}$ For the effects of insurance coverage, we found no significant interaction effects.
} 
Table 6: Proportions and characteristics of households with positive, non-significant and negative relationship of government relief expectation and flood mitigation.

\begin{tabular}{|l|c|c|l|}
\hline & \multicolumn{2}{|c|}{ Ratios in estimation sample } & \multirow{2}{*}{ Characteristics } \\
\cline { 2 - 3 } & Homeowners & Tenants & \\
\hline $\begin{array}{l}\text { Significantly }(p<.1) \text { positive sum of relief expectation } \\
\text { and interaction marginal effects }\end{array}$ & .391 & .102 & $\begin{array}{l}\text { No high education } \\
\text { and/or risk seeking }\end{array}$ \\
\hline $\begin{array}{l}\text { Sum of relief expectation and interaction effects not } \\
\text { significantly different from zero }\end{array}$ & .595 & .607 & \\
\hline $\begin{array}{l}\text { Significantly ( } p<.1 \text { ) negative sum of relief expectation } \\
\text { and interaction marginal effects (charity hazard) }\end{array}$ & .014 & .291 & $\begin{array}{l}\text { High education } \\
\text { and/or risk aversion }\end{array}$ \\
\hline
\end{tabular}

It becomes apparent that a charity hazard effect can be detected particularly for tenants with high education levels and high risk aversion. For other groups, the expectation of government relief seems not relevant for the decision whether to engage in mitigation or there is a counterintuitive positive relationship, comparable to the effect of perceived insurance coverage discussed above.

These results suggest that the relationship between expected damage coverage by a third party and flood mitigation is quite complex and deserves further research. But we can state that a significant moral hazard effect due to perceived insurance coverage is not detectable in our data. Significant charity hazard effects can be observed to some extent for a non-negligible minority of tenants.

\section{Conclusions}

In the present analysis the uptake of private flood mitigation measures has been analysed empirically using a large-scale household survey. It is the first analysis of this kind on the national level in a European country. By broadening the analysis to the national level, the results can indicate directions for the design of national policies stimulating private flood mitigation measures.

The main results can be summarized as in the following: Households which suffered financial or health damage from floods in the past have a higher probability to engage in private flood mitigation. On average, the predicted probability increases by $21.0 \%$ for homeowners (significant with $p<.01$ ) and $3.5 \%$ for tenants $(p<.1)$. Thus, the effect of damage experience found for flood-prone areas in previous literature can be confirmed for a nationwide household sample.

Beside the effect of damage experience, homeowners have a significantly higher probability to mitigate if they expect a climate change-induced increase of their personal flood damage in the next decades (predicted probability increases by more than $10 \%, p<.01$ ). As we explicitly asked for the additional effects expected due to climate change, this behaviour can be interpreted as private climate change adaptation. The magnitude of this adaptation signal is smaller than the effect of damage experience but significant and robust over various specifications for homeowners. We could not identify a comparable adaptation signal for flood mitigation of tenants. Interestingly, mitigation behaviour of homeowners is only significantly increasing in the middle range of a five-point damage expectation scale. In other words, it seems that there are lower and upper thresholds in the damage expectation levels. If damage expectation levels are below the lower threshold, adaptation is not detectable; likewise we cannot observe more intense adaptation if expectations are above the upper threshold and increase further. This result, however, may depend on the concrete formulation of the climate change expectation variable. If there are such threshold values, this will have important implications for the design of awareness and information campaigns. For example, an increase of 
climate change risk perception of already concerned individuals would not necessarily result in significantly higher private adaptation efforts.

The analysis has also shown that the (perceived) insurance coverage of flood damage does not reduce the motivation to engage in mitigation measures, at least for currently insured households. Hence, a crowding-out of private flood mitigation by insurance, as postulated by the moral hazard phenomenon, cannot be observed in our data. This means concerns about less private mitigation of insured households are not backed by our data. On the contrary, we find that insured households tend to engage in private flood mitigation measures rather than non-insured $(p<.01$ for homeowners). In the case of expecting government relief payments, we find that the effect on mitigation depends on individual characteristics, with some households increasing, other decreasing their mitigation efforts. In our data, significant charity hazard effects - i.e. less flood mitigation if financial government relief is expected - can be observed for a non-negligible minority of tenants, characterised by high levels of risk aversion and education.

A further policy-relevant result of our analysis is the apparent overestimation of flood insurance coverage among the German population. It seems that around a quarter of homeowners wrongly expect insurance coverage in case of a flood. This should be a further topic for awareness and information campaigns.

\section{References}

Bichard, Erik, and Aleksandra Kazmierczak. 2012. "Are Homeowners Willing to Adapt to and Mitigate the Effects of Climate Change?" Climatic Change 112(3-4):633-54. Retrieved May 5, 2012 (http://www.springerlink.com/index/10.1007/s10584-011-0257-8).

BMI. 2013. Bericht Zur Flutkatastrophe 2013: Katastrophenhilfe, Entschädigung, Wiederaufbau. Berlin, Germany.

Botzen, W. J. W., J. C. J. H. Aerts, and J. C. J. M. van den Bergh. 2009. "Willingness of Homeowners to Mitigate Climate Risk through Insurance." Ecological Economics 68(8-9):2265-77. Retrieved (http://www.sciencedirect.com/science/article/pii/S092180090900072X).

Botzen, W. J. W., J. C. J. H. Aerts, and J. C. J. M. van den Bergh. 2013. "Individual Preferences for Reducing Flood Risk to near Zero through Elevation." Mitigation and Adaptation Strategies for Global Change 18:229-44. Retrieved November 19, 2012 (http://www.springerlink.com/index/10.1007/s11027-012-9359-5).

Bubeck, P., W. J. W. Botzen, H. Kreibich, and J. C. J. H. Aerts. 2013. "Detailed Insights into the Influence of Flood-Coping Appraisals on Mitigation Behaviour." Global Environmental Change. Retrieved (http://www.sciencedirect.com/science/article/pii/S0959378013000836).

Carson, James M., Kathleen A. McCullough, and David M. Pooser. 2013. "Deciding Whether to Invest in Mitigation Measures: Evidence From Florida." Journal of Risk and Insurance 80(2):309-27. Retrieved November 13, 2012 (http://doi.wiley.com/10.1111/j.1539-6975.2012.01484.x).

Chatterjee, Chiradip, and Pallab Mozumder. 2014. "Understanding Household Preferences for Hurricane Risk Mitigation Information: Evidence from Survey Responses." Risk Analysis. Retrieved (http://dx.doi.org/10.1111/risa.12196). 
Choudhry, Umar. 2013. "Pflichtversicherung Gegen Elementarschäden Rückt Näher." AssCompact. Retrieved (http://www.asscompact.de/article/pflichtversicherung-gegen-elementarschaedenrueckt-naeher/assekuranz/y/contentpool/58361).

Ciscar, Juan-Carlos et al. 2011. "Physical and Economic Consequences of Climate Change in Europe." Proceedings of the National Academy of Sciences of the United States of America 108(7):267883. Retrieved March 29, 2012

(http://www.pubmedcentral.nih.gov/articlerender.fcgi?artid=3041092\&tool=pmcentrez\&rende rtype=abstract).

City of Copenhagen. 2012. The City of Copenhagen Cloudburst Management Plan 2012. Copenhagen, Denmark.

Deaton, Angus. 1997. The Analysis of Household Surveys. Baltimore, USA: John Hopkins University Press.

Die Bundesregierung. 2008. Deutsche Anpassungsstrategie an Den Klimawandel. Berlin, Germany.

Ehrlich, Isaac, and Gary S. Becker. 1972. "Market Insurance, Self-Insurance, and Self-Protection." Journal of Political Economy 80(4):623-48.

Feyen, Luc, J. I. Barredo, and R. Dankers. 2009. "Implications of Global Warming and Urban Land Use Change on Flooding in Europe." Pp. 217-25 in Water \& Urban Development Paradigms Towards an Integration of Engineering, Design and Management Approaches.

GDV. 2011. Auswirkungen Des Klimawandels Auf Die Schadensituation in Der Deutschen Versicherungswirtschaft. Berlin, Germany.

GDV. 2013. Naturgefahrenreport 2013. Berlin, Germany. Retrieved (http://www.gdv.de/wpcontent/uploads/2013/11/GDV-Naturgefahrenreport-Schadenchronik-2013.pdf).

GDV. 2014. "ZÜRS Public." Retrieved January 30, 2014 (http://www.zuers-public.de/zuerspublic/).

Grothmann, Torsten. 2005. "Klimawandel, Wetterextreme Und Private Schadensprävention." Magdeburg, Germany: Otto-von-Guericke-Universität Magdeburg.

Grothmann, Torsten, and Fritz Reusswig. 2006. "People at Risk of Flooding: Why Some Residents Take Precautionary Action While Others Do Not." Natural Hazards 38:101-20. Retrieved April 9, 2012 (http://www.springerlink.com/index/10.1007/s11069-005-8604-6).

Hattermann, Fred F., ZbigniewW. Kundzewicz, et al. 2013. "Climatological Drivers of Changes in Flood Hazard in Germany." Acta Geophysica 61(2):463-77. Retrieved (http://dx.doi.org/10.2478/s11600-012-0070-4).

Hattermann, Fred F., Shaochun Huang, et al. 2013. Modeling Flood Damages under Climate Change a Case Study for Germany. Potsdam, Germany.

Huber, Peter J. 1967. "The Behavior of Maximum Likelihood Estimates under Nonstandard Conditions." Pp. 221-33 in Proceedings of the Fifth Berkeley Symposium on Mathematical Statistics and Probability, Volume 1: Statistics, Fifth Berkeley Symposium on Mathematical Statistics and Probability. Berkeley, Calif.: University of California Press. Retrieved (http://projecteuclid.org/euclid.bsmsp/1200512988). 
IPCC. 2013. Climate Change 2013: The Physical Science Basis Summary for Policymakers.

Kandilioti, Georgia, and Christos Makropoulos. 2012. "Preliminary Flood Risk Assessment: The Case of Athens." Natural Hazards 61:441-68. Retrieved June 11, 2012

(http://www.springerlink.com/index/10.1007/s11069-011-9930-5).

Kievik, Milou, and Jan M. Gutteling. 2011. "Yes, We Can: Motivate Dutch Citizens to Engage in SelfProtective Behavior with Regard to Flood Risks." Natural Hazards 59(3):1475-90. Retrieved November 22, 2012 (http://www.springerlink.com/index/10.1007/s11069-011-9845-1).

Knocke, Ethan T., and Korine N. Kolivras. 2007. "Flash Flood Awareness in Southwest Virginia." Risk Analysis 27(1):155-69. Retrieved December 5, 2012 (http://www.ncbi.nlm.nih.gov/pubmed/17362407).

Koerth, Jana, Athanasios T. Vafeidis, Jochen Hinkel, and Horst Sterr. 2013. "What Motivates Coastal Households to Adapt pro-Actively to Sea-Level Rise and Increasing Flood Risk?" Regional Environmental Change 13:897-909. Retrieved (http://dx.doi.org/10.1007/s10113-012-0399-x).

Kreibich, H., S. Christenberger, and R. Schwarze. 2011. "Economic Motivation of Households to Undertake Private Precautionary Measures against Floods." Natural Hazards and Earth System Science 11(2):309-21. Retrieved July 4, 2013 (http://www.nat-hazards-earth-systsci.net/11/309/2011/).

Kreibich, H., A. H. Thieken, H. Grunenberg, K. Ullrich, and T. Sommer. 2009. "Extent, Perception and Mitigation of Damage due to High Groundwater Levels in the City of Dresden, Germany." Natural Hazards and Earth System Science 9(4):1247-58. Retrieved (http://www.nat-hazardsearth-syst-sci.net/9/1247/2009/).

Kreibich, H., A. H. Thieken, Th. Petrow, M. Müller, and B. Merz. 2005. "Flood Loss Reduction of Private Households due to Building Precautionary Measures - Lessons Learned from the Elbe Flood in August 2002." Natural Hazards and Earth System Science 5(1):117-26. Retrieved (http://www.nat-hazards-earth-syst-sci.net/5/117/2005/).

Kreibich, Heidi, and Annegret H. Thieken. 2008. "Coping with Floods in the City of Dresden, Germany." Natural Hazards 51:423-36. Retrieved June 4, 2012 (http://www.springerlink.com/index/10.1007/s11069-007-9200-8).

Lindell, Michael K., and Seong Nam Hwang. 2008. "Households' Perceived Personal Risk and Responses in a Multihazard Environment." Risk Analysis 28(2):539-56. Retrieved October 30, 2012 (http://www.ncbi.nlm.nih.gov/pubmed/18419668).

Mennel, Tim, and Daniel Osberghaus. 2013. "Klimawandel Und Versicherungsbranche: Benötigen Wir Eine Versicherungspflicht Gegen Elementarschäden?” Ökologisches Wirtschaften (2):2013.

Miceli, Renato, Igor Sotgiu, and Michele Settanni. 2008. "Disaster Preparedness and Perception of Flood Risk: A Study in an Alpine Valley in Italy." Journal of Environmental Psychology 28:164-73. Retrieved April 24, 2012 (http://linkinghub.elsevier.com/retrieve/pii/S0272494407000904).

Osberghaus, Daniel, Claudia Schwirplies, and Andreas Ziegler. 2013. Klimawandel in Deutschland: Risikowahrnehmung, Wissensstand Und Anpassung in Privaten Haushalten. Mannheim, Germany. Retrieved (http://www.rwi-essen.de/forschung-und-beratung/umwelt-undressourcen/projekte/eval-map/ergebnisse/). 
Petrolia, Daniel R., Joonghyun Hwang, Craig E. Landry, and Keith H. Coble. 2013. Wind Insurance and Mitigation in the Coastal Zone.

Poussin, Jennifer K., W. J. Wouter Botzen, and Jeroen C. J. H. Aerts. 2013. "Stimulating Flood Damage Mitigation through Insurance: An Assessment of the French CatNat System." Environmental Hazards 12(3-4):258-77. Retrieved (http://www.tandfonline.com/doi/abs/10.1080/17477891.2013.832650).

Raschky, Paul A., Reimund Schwarze, Manijeh Schwindt, and Ferdinand Zahn. 2013. "Uncertainty of Governmental Relief and the Crowding out of Flood Insurance." Environmental and Resource Economics 54:179-200. Retrieved November 19, 2012 (http://www.springerlink.com/index/10.1007/s10640-012-9586-y).

Raschky, Paul A., and Hannelore Weck-Hannemann. 2007. "Charity hazard-A Real Hazard to Natural Disaster Insurance?” Environmental Hazards 7(4):321-29. Retrieved May 7, 2012 (http://tandfprod.literatumonline.com/doi/abs/10.1016/j.envhaz.2007.09.002).

Rojas, Rodrigo, Luc Feyen, and Paul Watkiss. 2013. "Climate Change and River Floods in the European Union: Socio-Economic Consequences and the Costs and Benefits of Adaptation." Global Environmental Change 23(6):1737-51. Retrieved (http://www.sciencedirect.com/science/article/pii/S0959378013001416).

Schwarze, Reimund, and Gert G. Wagner. 2004. "In the Aftermath of Dresden: New Directions in German Flood Insurance." The Geneva Papers on Risk and Insurance 29(2):154-68.

Siegrist, Michael, and Heinz Gutscher. 2008. "Natural Hazards and Motivation for Mitigation Behavior: People Cannot Predict the Affect Evoked by a Severe Flood." Risk Analysis 28(3):77178. Retrieved October 26, 2012 (http://www.ncbi.nlm.nih.gov/pubmed/18643832).

Takao, Kenji et al. 2004. "Factors Determining Residents' Preparedness for Floods in Modern Megalopolises: The Case of the Tokai Flood Disaster in Japan." Journal of Risk Research 7(78):775-87.

Terpstra, T., and M. K. Lindell. 2012. “Citizens' Perceptions of Flood Hazard Adjustments: An Application of the Protective Action Decision Model." Environment and Behavior. Retrieved November 13, 2012 (http://eab.sagepub.com/cgi/doi/10.1177/0013916512452427).

Thieken, Annegret H., Heidi Kreibich, Meike Müller, and Bruno Merz. 2007. "Coping with Floods: Preparedness, Response and Recovery of Flood-Affected Residents in Germany in 2002." Hydrological Sciences Journal 52(5):1016-37.

Thieken, Annegret H., Meike Müller, Heidi Kreibich, and Bruno Merz. 2005. "Flood Damage and Influencing Factors: New Insights from the August 2002 Flood in Germany." Water Resources Research 41(12). Retrieved November 28, 2012 (http://www.agu.org/pubs/crossref/2005/2005WR004177.shtml).

Thieken, Annegret H., Theresia Petrow, Heidi Kreibich, and Bruno Merz. 2006. "Insurability and Mitigation of Flood Losses in Private Households in Germany." Risk Analysis 26(2):383-95. Retrieved March 12, 2012 (http://www.ncbi.nlm.nih.gov/pubmed/16573628).

Veronesi, Marcella, Fabienne Chawla, Max Maurer, and Judit Lienert. 2013. "Climate Change and the Willingness to Pay to Reduce Ecological and Health Risks from Wastewater Flooding in Urban 
Centers and the Environment." Ecological Economics 2919(January):1-10. Retrieved March 7, 2014 (http://linkinghub.elsevier.com/retrieve/pii/S0921800913003601).

Wasserhaushaltsgesetz. 2009. Gesetz Zur Ordnung Des Wasserhaushalts (Wasserhaushaltsgesetz WHG ). Germany.

White, Halbert. 1980. "A Heteroskedasticity-Consistent Covariance Matrix Estimator and a Direct Test for Heteroskedasticity." Econometrica 48(4):817-38. Retrieved (http://www.jstor.org/stable/1912934).

White, Halbert. 1982. "Maximum Likelihood Estimation of Misspecified Models." Econometrica 50(1):1-25. Retrieved (http://www.jstor.org/stable/1912526).

Zaalberg, Ruud, Cees Midden, Anneloes Meijnders, and Teddy McCalley. 2009. "Prevention, Adaptation, and Threat Denial: Flooding Experiences in the Netherlands." Risk Analysis 29(12):1759-78. Retrieved November 22, 2012 (http://www.ncbi.nlm.nih.gov/pubmed/19919550).

Zhai, Guofang, Teruko Sato, Teruki Fukuzono, Saburo Ikeda, and Kentaro Yoshida. 2006. "Willingness to Pay for Flood Risk Reduction and Its Determinants in Japan." JAWRA Journal of the American Water Resources Association 42(4):927-40. Retrieved (http://dx.doi.org/10.1111/j.17521688.2006.tb04505.x).

\section{Acknowledgements}

I would like to thank Jürgen Bitzer, Klaus Eisenack, Manuel Frondel, Katherine von Graevenitz as well as François Laisney for useful comments and fruitful discussions.

Financial support of the German Ministry for Education and Research (BMBF) is gratefully acknowledged. The funding source had no involvement in study design, collection, analysis and interpretation of the data, and writing of the article.

\section{Appendix}

Table 7: Descriptive statistics of control variables (full sample of potentially exposed households). n.r.: not reported in detail

\begin{tabular}{|l|l|r|r|r|r|r|r|}
\hline $\begin{array}{l}\text { Variable in } \\
\text { the model }\end{array}$ & Variable in the data & \multicolumn{1}{l|}{ Mean } & \multicolumn{1}{l|}{ Median } & \multicolumn{1}{l|}{ Std. Err. } & \multicolumn{1}{l}{ Min. } & Max. \\
\hline Age & Age in years & 51.2 & 52 & 13.1 & 18 & 87 & 5851 \\
\hline Gender & Gender (1 = female) & .320 & 0 & .467 & 0 (male) & 1 (female) & 5851 \\
\hline Children & $\begin{array}{l}\text { Number of children under the } \\
\text { age of 18 living in household }\end{array}$ & .383 & 0 & .777 & 0 & 5 & 5639 \\
\hline \multirow{2}{*}{ Education } & $\begin{array}{l}\text { Graduated from 'Hauptschule' } \\
\text { or not graduated }\end{array}$ & .149 & 0 & .356 & 0 (no) & 1 (yes) & 5647 \\
\cline { 2 - 8 } & $\begin{array}{l}\text { Graduated from 'Realschule' } \\
\text { or rest }\end{array}$ & .380 & 0 & .485 & 0 (no) & 1 (yes) & 5647 \\
\hline
\end{tabular}




\begin{tabular}{|c|c|c|c|c|c|c|c|}
\hline $\begin{array}{l}\text { Variable in } \\
\text { the model }\end{array}$ & Variable in the data & Mean & Median & Std. Err. & Min. & Max. & Obs. \\
\hline & $\begin{array}{l}\text { Graduated from high school or } \\
\text { university }\end{array}$ & .472 & 0 & .499 & 0 (no) & 1 (yes) & 5647 \\
\hline \multirow{6}{*}{ Occupation } & Full-time employed & .602 & 0 & .489 & 0 (no) & 1 (yes) & 5597 \\
\hline & Part-time employed & .135 & 0 & .341 & 0 (no) & 1 (yes) & 5597 \\
\hline & Retired & .228 & 0 & .420 & 0 (no) & 1 (yes) & 5597 \\
\hline & $\begin{array}{l}\text { Unemployed, searching for } \\
\text { employment }\end{array}$ & .0143 & 0 & .119 & 0 (no) & 1 (yes) & 5597 \\
\hline & Housewife /-husband & .00465 & 0 & .0680 & 0 (no) & 1 (yes) & 5597 \\
\hline & $\begin{array}{l}\text { Other unemployed, not } \\
\text { searching for employment }\end{array}$ & .0159 & 0 & .125 & 0 (no) & 1 (yes) & 5597 \\
\hline Income & Household income in $€$ & 2887 & 2750 & 1324 & 250 & 5750 & 4862 \\
\hline Homeowner & Ownership of the residence & .583 & 1 & .493 & 0 (no) & 1 (yes) & 5809 \\
\hline \multirow{2}{*}{$\begin{array}{l}\text { Personal } \\
\text { attitudes }\end{array}$} & $\begin{array}{l}\text { Stated general willingness to } \\
\text { take risks, measured by } 11 \text { - } \\
\text { point Likert scale }\end{array}$ & 5.824 & 6 & 2.034 & 1 & 11 & 5844 \\
\hline & $\begin{array}{l}\text { Own financial situation is very } \\
\text { important }\end{array}$ & .483 & 0 & .500 & 0 (no) & 1 (yes) & 5846 \\
\hline \multirow{5}{*}{ Exposure } & $\begin{array}{l}16 \text { Dummy variables for each } \\
\text { federal state }\end{array}$ & n.r. & n.r. & n.r. & 0 & 1 & 5851 \\
\hline & Population of the municipality & 355,475 & 34,069 & 822,764 & 33 & $3,501,872$ & 5816 \\
\hline & $\begin{array}{l}\text { Historical precipitation in } \\
\text { wettest month }(\mathrm{mm})\end{array}$ & 86.2 & 81 & 22 & 55.1 & 265.9 & 5844 \\
\hline & River in ZIP code area & .618 & 1 & .486 & 0 & 1 & 5844 \\
\hline & Only basement exposed & .336 & 0 & .472 & 0 & 1 & 5851 \\
\hline Knowledge & $\begin{array}{l}\text { Knowing the insurance } \\
\text { industry risk class of the own } \\
\text { residence }\end{array}$ & .0256 & 0 & .158 & 0 (no) & 1 (yes) & 5775 \\
\hline
\end{tabular}

Table 8: Questions and answer options of the key variables flood mitigation measures, flood damage experience, and damage expectations (translated from German). The 'don't know'-option was possible in each question.

\begin{tabular}{|c|c|c|}
\hline $\begin{array}{l}\text { Variable in } \\
\text { the model }\end{array}$ & Questionnaire item & Answer options \\
\hline $\begin{array}{l}\text { Private } \\
\text { flood } \\
\text { mitigation }\end{array}$ & $\begin{array}{l}\text { Only potentially flood exposed households were asked; the measures were } \\
\text { filtered as such that only applicable households could choose them (see Table } \\
\text { 1) } \\
\text { Please indicate which of the following flood mitigation measures you have } \\
\text { already implemented in your household and which you are planning to } \\
\text { implement in the near future: } \\
\text { - Moving valuable assets to higher floors } \\
\text { - Water barriers at basement openings } \\
\text { - Back flow flap } \\
\text { - Water-resistant exterior paint coat } \\
\text { - Water-resistant interior paint coat } \\
\text { - Water-resistant floor }\end{array}$ & $\begin{array}{ll}- & \text { Already } \\
\text { implemented } \\
\text { - } & \text { Implementation } \\
& \text { planned for the } \\
\text { near future } \\
\text { - } & \text { Neither } \\
\text { implemented nor } \\
\text { planned }\end{array}$ \\
\hline
\end{tabular}




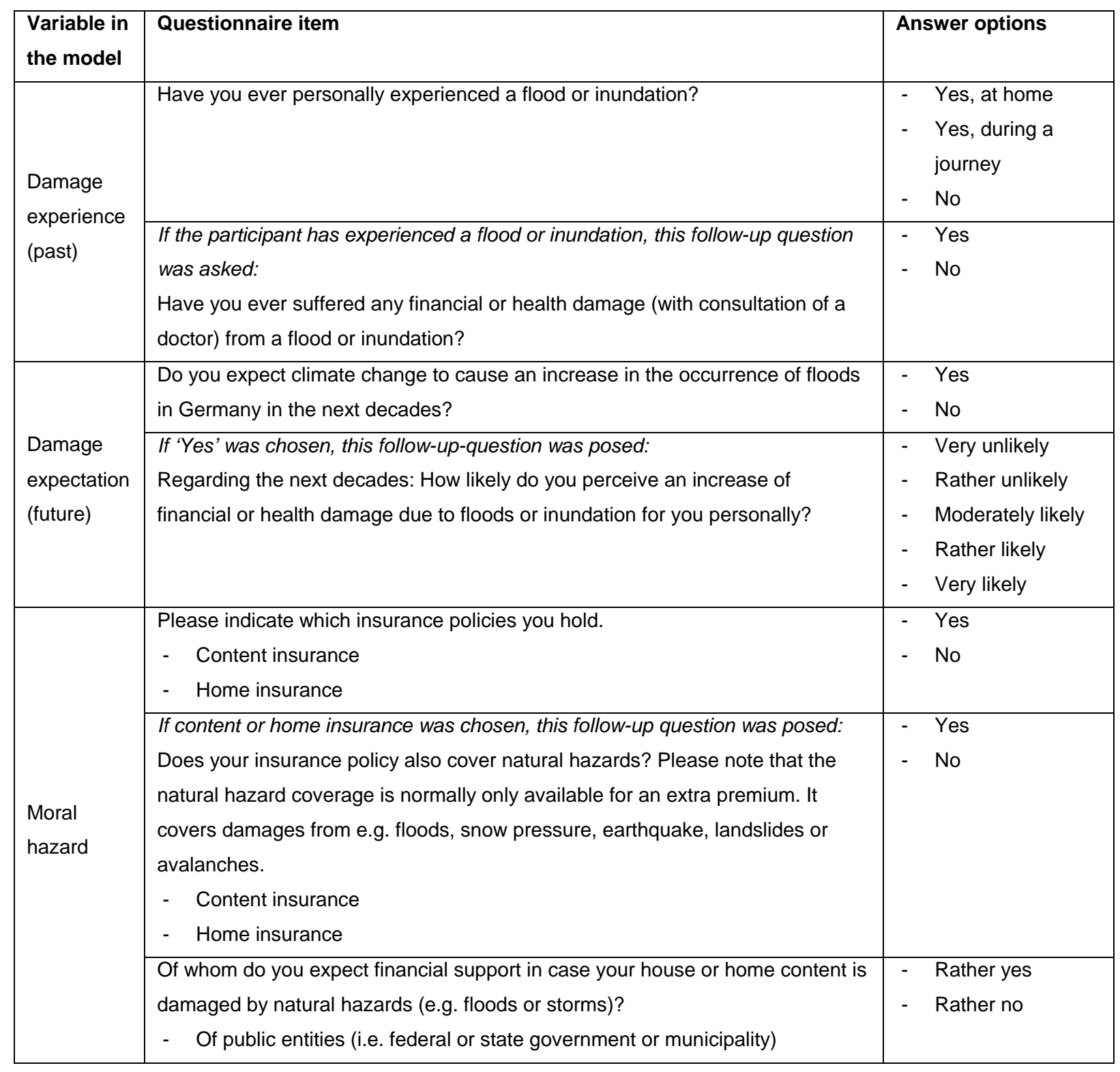

Table 9: Results of probit regressions (Model 3). Dependent variable: Uptake of any private flood mitigation measure (binary). */**/*** symbolise statistical significance on the $10 / 5 / 1 \%$ level.

\begin{tabular}{|l|l|l|l|}
\hline $\begin{array}{l}\text { Variable in } \\
\text { the model }\end{array}$ & Variable in the data & $\begin{array}{l}\text { Average marginal } \\
\text { effects }\end{array}$ & $\begin{array}{l}\text { Robust } \\
\text { standard errors }\end{array}$ \\
\hline Age & Age in years & $.00157^{* *}$ & .000709 \\
\hline Gender & Gender (1 = female) & $.0262^{*}$ & .0148 \\
\hline Children & Number of children under the age of 18 living in household & .00253 & .00839 \\
\hline \multirow{4}{*}{ Education } & Graduated from 'Hauptschule' or not graduated & .00637 & .0179 \\
\cline { 2 - 4 } & Graduated from 'Realschule' or rest & \multicolumn{2}{|c|}{ reference group } \\
\cline { 2 - 4 } & Graduated from high school or university & .00873 & \multicolumn{2}{|c|}{ reference group } \\
\hline \multirow{5}{*}{ Occupation } & Full-time employed & $.0441^{* *}$ & .0198 \\
\cline { 2 - 4 } & Part-time employed & $.0478^{* *}$ & .0186 \\
\cline { 2 - 4 } & Retired & $.102^{* *}$ & .0502 \\
\cline { 2 - 4 } & Unemployed, searching for employment & -.115 & .0785 \\
\cline { 2 - 4 } & Housewife /-husband & $-.126^{*}$ & .0705 \\
\cline { 2 - 4 } & Other unemployed, not searching for employment & $.0000204^{* * *}$ & $5.13 e^{-6}$ \\
\hline \multirow{2}{*}{ Income } & Household income in $€$ & \multicolumn{2}{|c|}{} \\
\hline
\end{tabular}




\begin{tabular}{|c|c|c|c|c|}
\hline $\begin{array}{l}\text { Variable in } \\
\text { the model }\end{array}$ & \multicolumn{2}{|l|}{ Variable in the data } & $\begin{array}{l}\text { Average marginal } \\
\text { effects }\end{array}$ & $\begin{array}{l}\text { Robust } \\
\text { standard errors }\end{array}$ \\
\hline Homeowner & \multicolumn{2}{|l|}{ Ownership of the residence } & $.338 * * *$ & .0346 \\
\hline \multirow{2}{*}{$\begin{array}{l}\text { Personal } \\
\text { attitudes }\end{array}$} & \multicolumn{2}{|l|}{ Stated general willingness to take risks } & $.00550^{*}$ & .00299 \\
\hline & \multicolumn{2}{|l|}{ Own financial situation very important } & $.0266 * *$ & .0120 \\
\hline \multirow{5}{*}{ Exposure } & \multicolumn{2}{|c|}{$\begin{array}{l}15 \text { Dummy variables for federal states (reference group North } \\
\text { Rhine-Westphalia) }\end{array}$} & \multicolumn{2}{|c|}{ included } \\
\hline & \multicolumn{2}{|l|}{ Population of the municipality } & $-6.36 \mathrm{e}^{-8 * *}$ & $3.07 e^{-8}$ \\
\hline & \multicolumn{2}{|l|}{ Historical precipitation in wettest month } & $-.00132 * * *$ & .000329 \\
\hline & \multicolumn{2}{|l|}{ River in ZIP code area } & -.00967 & .0126 \\
\hline & \multicolumn{2}{|l|}{ Only basement exposed } & -.00777 & .0165 \\
\hline Knowledge & \multicolumn{2}{|c|}{ Knowing the insurance industry risk class of the own residence } & $.111^{* * *}$ & .0335 \\
\hline \multirow{2}{*}{$\begin{array}{l}\text { Damage } \\
\text { experience }\end{array}$} & \multicolumn{2}{|c|}{$\begin{array}{l}\text { Household has already experienced financial or health damage by } \\
\text { floods (homeowners) }\end{array}$} & $.210^{* * *}$ & .0297 \\
\hline & \multicolumn{2}{|c|}{$\begin{array}{l}\text { Household has already experienced financial or health damage by } \\
\text { floods (tenants) }\end{array}$} & $.0350^{*}$ & .0181 \\
\hline \multirow{12}{*}{$\begin{array}{l}\text { Damage } \\
\text { expectations }\end{array}$} & \multicolumn{2}{|l|}{ Personal damage increase is ... } & & \\
\hline & ... very unlikely & \multirow{5}{*}{ Homeowners } & \multicolumn{2}{|c|}{ reference group } \\
\hline & ... rather unlikely & & .0199 & .0217 \\
\hline & ... moderately likely & & $.0740 * * *$ & .0261 \\
\hline & ... rather likely & & $.122 * * *$ & .0357 \\
\hline & ... very likely & & .0677 & .0667 \\
\hline & \multicolumn{2}{|l|}{ Personal damage increase is ... } & & \\
\hline & ... very unlikely & \multirow{5}{*}{ Tenants } & \multicolumn{2}{|c|}{ reference group } \\
\hline & ... rather unlikely & & .00688 & .0111 \\
\hline & ... moderately likely & & .0173 & .0141 \\
\hline & ... rather likely & & $.0403^{*}$ & .0233 \\
\hline & ... very likely & & .0236 & .0343 \\
\hline \multirow{4}{*}{ Moral hazard } & \multicolumn{2}{|l|}{$\begin{array}{l}\text { Stated flood coverage of home or content insurance } \\
\text { (homeowners) }\end{array}$} & $.0969 * * *$ & .0201 \\
\hline & \multicolumn{2}{|c|}{ Stated flood coverage of home or content insurance (tenants) } & $.0221 * *$ & .0107 \\
\hline & \multicolumn{2}{|c|}{ Stated expectation of financial government relief (homeowners) } & $.0388^{*}$ & .0202 \\
\hline & \multicolumn{2}{|c|}{ Stated expectation of financial government relief (tenants) } & .00324 & .00967 \\
\hline \multicolumn{3}{|l|}{ Pseudo-R2 } & \multicolumn{2}{|c|}{.253} \\
\hline \multicolumn{3}{|l|}{$\mathrm{N}$} & \multicolumn{2}{|c|}{4272} \\
\hline
\end{tabular}

